University of Michigan Law School

University of Michigan Law School Scholarship Repository

Law \& Economics Working Papers

$1-1-2014$

Just Say No: Corporate Taxation and Corporate Social Responsibility

Reuven S. Avi-Yonah

University of Michigan Law School, aviyonah@umich.edu

Follow this and additional works at: https://repository.law.umich.edu/law_econ_current

Part of the Business Organizations Law Commons, and the Tax Law Commons

Working Paper Citation

Avi-Yonah, Reuven S., "Just Say No: Corporate Taxation and Corporate Social Responsibility" (2014). Law \& Economics Working Papers. 102.

https://repository.law.umich.edu/law_econ_current/102

This Article is brought to you for free and open access by University of Michigan Law School Scholarship Repository. It has been accepted for inclusion in Law \& Economics Working Papers by an authorized administrator of University of Michigan Law School Scholarship Repository. For more information, please contact mlaw.repository@umich.edu. 
DRAFT 4/13/14

\title{
JUST SAY NO: CORPORATE TAXATION AND CORPORATE SOCIAL RESPONSIBILITY
}

\author{
Reuven S. Avi-Yonah ${ }^{1}$
}

The imposition of taxes and the expenditure of tax proceeds are governmental functions...The whole justification for permitting the corporate executive to be selected by the stockholders is that the executive is an agent serving the interests of his principal. This justification disappears when the corporate executive imposes taxes and spends the proceeds for "social" purposes.

\section{Milton Friedman ${ }^{2}$}

\section{Introduction: The Caterpillar Profit Shifting Strategy}

This article will address the question whether publicly traded US corporations owe a duty to their shareholders to minimize their corporate tax burden in any way that they may be able to get away with from a purely legal perspective. First, however, to render the subsequent discussion a bit more concrete, I will describe a recently unveiled case study of corporate tax aggressiveness. ${ }^{3}$

Caterpillar, Inc. is "the world's leading manufacturer of construction and mining equipment, diesel and natural gas engines, industrial gas turbines and diesel-electric locomotives." ${ }^{4}$ Founded in 1925, "[f]or more than 85 years, Caterpillar Inc. has been

\footnotetext{
${ }^{1}$ Irwin I. Cohn Professor of Law and Director, International Tax LLM, The University of Michigan. A previous version of this paper appeared as Corporate Social Responsibility and Strategic Tax Behavior, in Wolfgang Schoen (ed.), Tax and Corporate Governance, 183 (2008). I would like to thank Peter Barnes, Joshua Blank, David Hasen, Bob Kuttner, Sagit Leviner, Michael Schler, Wolfgang Schoen, Helen Scott, Dganit Sivan, Pekka Timmonen, and participants in workshops at Georgetown Law Center, the Interdisciplinary Center- Herzeliya, the Max Planck Institute for Intellectual Property, Competition and Tax Law and NYU Law School.

${ }^{2}$ Milton Friedman, The Social Responsibility of Business Is To Increase Its Profits, NY Times SM17 (Sept. 13, 1970).

${ }^{3}$ The following is based on my testimony before the US Senate Permanent Subcommittee on Investigations, April 1, 2014.

${ }^{4}$ www.caterpillar.com.
} 
making progress possible and driving positive and sustainable change on every continent."

A major reason for Caterpillar's success has been its ability to service the equipment that it sells worldwide. Caterpillar promises to deliver any replacement part anywhere in the world within 24 hours from when a customer requests it. This logistical feat puts Caterpillar far ahead of its competitors and is also a major source of profitability. ${ }^{6}$ While Caterpillar's profit margin on selling equipment is typically below $10 \%$, its profit margin on parts is typically over $50 \% .^{7}$ In some years, $80 \%$ of Caterpillar's profits derived from parts sales. ${ }^{8}$

Caterpillar's business model is based on a network on independent dealers, some of whom have been selling the company's products for over sixty years. Currently, there are 178 dealers worldwide, 48 of whom are outside the US, and they employ 162,000 people. Caterpillar's dealer network is tightly controlled from the US, and the company has recently announced that it will centralize its supervision of the dealer network even more tightly than before.

Before 1999, Caterpillar's purchased finished parts business was run primarily from Morton, Illinois, where the company maintains its main parts warehouse. ${ }^{9}$ When a part was manufactured in the US or overseas, it would be shipped to Morton, and from Morton it would be shipped either directly to a customer or to a dealer. ${ }^{10}$ Caterpillar owned the parts in the Morton warehouse. This business model enabled Caterpillar to

\footnotetext{
${ }^{5}$ www.caterpillar.com/history.

6 "Caterpillar Logistics Services, Inc. (Cat Logistics) has leveraged its relationship with parent company Caterpillar Inc. in developing true global supply chain management capabilities. Cat Logistics has grown to be the sixth largest North American based 3PL with $\$ 1.1$ billion in net revenues in 2003 . It has been attracting significant external business; Caterpillar, Inc. now accounts for approximately 50\% of the Cat Logistics revenues. Plans are to grow external business at a compound annual growth rate of $26 \%$ over the next five years.” Evan Armstrong, Caterpillar Logistics, a True Global Supply Chain Manager, Morton, Illinois, January 11, 2005. According to an internal CAT email from 2007, machines can consume profitable replacement parts for up to 20 years, and there was little or no competition for such parts. ${ }^{7}$ According to a PwC study from October 1999, Caterpillar's return on sales on "prime", or equipment, was $2 \%$, while its return on purchased finished parts was $21 \%$.

${ }^{8}$ CSARL 2006 Royalty Rate Study (11/14/05).

${ }^{9}$ In $1999,83 \%$ of Caterpillar's worldwide parts were exported from the US.

${ }^{10}$ The majority of the parts suppliers are in the US. Steines testimony, 3.
} 
control the flow of parts and to ensure that its promise of delivering parts to customers within 24 hours would be kept.

In September 1998, PriceWaterhouseCoopers (“PwC”), Caterpillar's auditor, presented a plan to Caterpillar management that was explicitly designed to reduce Caterpillar's US effective tax rate. The first recommendation in the PwC plan was to restructure the parts business. ${ }^{11}$ Under the pre-1999 structure, any profit that Caterpillar made from selling parts directly to customers in the US or overseas was taxed by the US. Moreover, any profit that Caterpillar's foreign subsidiaries made on selling parts they acquired from Caterpillar to their customers was also taxed by the US because it was "Subpart F income" and therefore resulted in a deemed dividend to Caterpillar under IRC sections $951-960$. About $85 \%$ of the total profits were earned directly by Caterpillar, while the other $15 \%$ were Subpart F income.

PwC proposed to set up a Swiss entity, Caterpillar Sarl (“CSARL”), which would be treated as a corporation for Swiss tax purposes but as a partnership for US tax purposes (this was possible under the newly adopted "check the box" regime for classifying foreign entities for US tax purposes). The partners in CSARL were two Swiss subsidiaries of Caterpillar. CSARL would then assume ownership of the parts in the Morton warehouse. If those parts were intended for the US market, CSARL would sell them to Caterpillar at no profit, and Caterpillar would resell them and report the profits on its US tax return like it did before 1999. However, if the parts were intended for customers overseas, CSARL would sell them to independent dealers, which would resell to the non-USA customers, with the bulk of the profit going to CSARL. ${ }^{12}$

The purpose of this structure was to avoid paying US tax on the profits from the sale of parts to non-US customers by eliminating Caterpillar from the supply chain. The

\footnotetext{
${ }^{11}$ PwC, Caterpillar Plan, Appendix C, Solution 1 (September, 1998). Overall, PwC was paid about $\$ 55$ million for its contribution to reducing Caterpillar's US taxes.

${ }^{12}$ For example, if before the restructuring Caterpillar would buy a part from a supplier for 2 and sell it to a Swiss marketing subsidiary for 8 , who would in turn sell to a customer or dealer outside Switzerland for 10, the result would be that Caterpillar would pay US tax on 8 ( 6 of its own profit and 2 Subpart F deemed dividend from the Swiss subsidiary). After the restructuring CSARL would buy the part from the supplier for 2 and sell directly to a dealer outside Switzerland for 10, and the resulting profit of 8 would belong to CSARL and not be Subpart F income because under Subpart F base company income does not include profits from sales for resale if both transactions are with unrelated parties.
} 
parts would be purchased directly by CSARL from suppliers and sold directly by CSARL to the independent dealers overseas, without ownership passing through Caterpillar. This would avoid Subpart F because it does not apply to sales by CSARL to unrelated parties outside Switzerland unless the parts were acquired from a related party (i.e., Caterpillar).

However, physically nothing was changed. The parts were still shipped by the suppliers to Morton and shipped by Caterpillar from Morton to the independent dealers, without any involvement by CSARL. ${ }^{13}$ Caterpillar still ran the logistics business as it did before, except that it did so as an agent for CSARL, the owner of the parts destined for foreign markets. CSARL had no warehouse or inventory management system, and the parts business remained "US centric." ${ }^{14}$ Moreover, there was no physical distinction at Morton between parts destined for the US market (and therefore sold to Caterpillar at zero profit) and parts destined overseas. All the parts were inventoried by Caterpillar as before, except that a "virtual inventory" was created to track for tax purposes whether any given part was owned by Caterpillar or by CSARL at any given moment. ${ }^{15}$ Moreover, if a part intended for the US or overseas was missing, Caterpillar would "borrow" the part from CSARL, or vice versa, and restore it later as new parts came in (of course, without affecting the physical movement of any part).${ }^{16}$ Currently, nearly $70 \%$ of the purchased finished parts Caterpillar sells overseas come from the US, and the parts business continues to be led and managed from the US. ${ }^{17}$

\footnotetext{
${ }^{13}$ According to Craig Barley, a senior CAT manager, in the early 2000s $85 \%$ of Cat's worldwide parts inventory was managed from Morton, and 296 of the 300 employees involved in the parts business were located at Morton. The aim, however, was to increase the inventory managed from Morton to $100 \%$. PWCPSI-CAT00179037. A February 2012 memo to the board described the "as is" parts business as worldwide suppliers shipping parts to the "master distribution center" in Morton, from which they were shipped to distributors both in the US and overseas. The memo discusses future plans to open more warehouses overseas (e.g., in Dubai) to reduce the shipping costs of this US-centric structure.

${ }^{14}$ Caterpillar board minutes, February 8, 2012. For example, all of the inventory in the Grimbergen facility overseas was controlled from Morton, 5,000 and 8,000 employees involved in the parts business were in the US, and 5 of 8 parts warehouses were in North America. CAT 001896 (Feb. 2012); CAT 0002791 (December 2013). CSARL has 400 employees, or less than $0.5 \%$ of Caterpillar's workforce (Steines report, 4).

${ }^{15}$ Physically, the parts were indistinguishable and kept in the same bin. Stiles deposition.

${ }^{16}$ Over time, CSARL also acquired parts from Caterpillar facilities in France and Belgium, which were shipped directly from these facilities to CSARL's customers. The French and Belgian suppliers were reimbursed on a contract manufacturing basis so once again the bulk of the profit was allocated to CSARL as the "entrepreneur" in this transaction.

${ }^{17}$ CAT 001866 (March 7, 2014); Steines report, 5.
} 
This "business restructuring" enabled Caterpillar to shift over $\$ 8$ billion in the period from 2000 to 2012 from the US to Switzerland without affecting the actual way in which the parts business was run. ${ }^{18}$ In fact, it was important to Caterpillar not to change the successful business model of its parts and parts delivery business, and therefore the tax department reimbursed the parts and parts delivery segments of Caterpillar for any added costs resulting from the restructuring. This resulted in maintaining the "accountable profits" of each segment of the business as if the restructuring had not taken place, which was crucial to achieving cooperation since accountable profits formed the basis for setting compensation levels. ${ }^{19}$ Nor were any personnel involved in the parts business moved to CSARL when it took over as nominal owner of all the parts in Morton. $^{20}$

In order to defend this restructuring from a transfer pricing challenge by the IRS, PwC calculated a royalty rate of $15 \%$ (later reduced to $4 \%$ to $6 \%$ ) to be paid by CSARL to Caterpillar to compensate it for any value inherent in its contribution to CSARL's parts related profits. The royalty rate was based on a comparability study performed by $\mathrm{PwC} .^{21}$ If this royalty rate could be defended in court, the result would be a successful shift of $85 \%$ of the total profit from parts business from the US $(30.5 \%$ effective tax rate on Caterpillar) to Switzerland (4\% effective tax rate on CSARL). The total tax benefit to Caterpillar from this shift over the period from 2000 to 2012 was approximately $\$ 2.4$ billion.

Does this transaction pass muster? In my opinion, the answer is no, because it does not have economic substance.

The economic substance doctrine was a well-established part of tax law long before it was codified as IRC section 7701(o) in 2010. As developed by the courts, in

\footnotetext{
${ }^{18}$ Copeland deposition, Rapp deposition.

${ }^{19}$ Springer deposition.

${ }^{20}$ Stiles deposition.

${ }^{21}$ See PwC Transfer Pricing Documentation for Caterpillar, September, 2001. The fixed royalty rate assumes that Caterpillar did not transfer any intangibles to CSARL and therefore was not subject to the "super royalty" rule of IRC sections $367(\mathrm{~d})$ and 482 (which would require an adjustable royalty commensurate with the income attributable to a transferred intangible unless a cost-sharing agreement was in effect).
} 
order for a transaction to be respected for tax purposes, it must satisfy either or both prongs of the economic substance test, which are (a) the subjective prong, i.e., that the taxpayer or its agents believe that the transaction has a valid non-tax business purpose, and (b) the objective prong, i.e., that the transaction has a reasonable possibility of generating a profit regardless of the tax consequences.

The IRS could argue that the Caterpillar restructuring fails to meet either prong (under the codified version it must satisfy both). On the subjective prong, the PwC documentation from 1998 onward is clear that the main purpose of the restructuring was to reduce Caterpillar's effective tax rate by removing the parent company from the parts supply chain, thereby avoiding Subpart F deemed dividends and achieving deferral for CSARL's profits. ${ }^{22}$ Moreover, a senior Caterpillar executive was asked under oath "was there any business advantage to CAT to have this arrangement put in place other than the avoidance or deferral of income taxation at a higher rate," and he answered in the negative. $^{23}$

On the objective prong, while CSARL's parts business is very profitable, it is hard to see what the non-tax reason could be for changing the structure from sales by Caterpillar to sales by CSARL. The entire restructuring was done so as not to change the business model of the parts business. No significant employees were moved to CSARL, the parts continued to be shipped to and from Morton by Caterpillar, and the physical parts were indistinguishable. Moreover, steps were taken to separate the ownership for tax purposes under the "virtual inventory" from the actual inventory, which remained in Caterpillar. It is true that over time CSARL assumed ownership of more parts that were not shipped through the US, but it is still hard to see what was and is the business purpose of CSARL nominally owning the parts shipped via Morton, including the parts it sells at cost to Caterpillar.

\footnotetext{
${ }^{22}$ See PwC documentation from September 1998, December 1998 and September 1999; see also Caterpillar, Delivering Vision 2020 (2009), which explains the tax advantage of the restructuring.

${ }^{23}$ Perkins deposition.
} 
Caterpillar did subsequently try to bolster CSARL against a potential IRS challenge by moving some employees (including a "worldwide parts manager") to Geneva to "provide added entrepreneurial substance" and to "reinforce CSARL's role as entrepreneur for global parts sales." ${ }^{24}$ But these late efforts, coming ten years after the restructuring, only reinforce the sense that the original transaction lacked economic substance, especially since the parts business continued to be managed from the US. ${ }^{25}$

Caterpillar could attempt to rebut the IRS challenge by relying on the UPS case, an 11th Circuit decision from 2001. ${ }^{26}$ In UPS, the taxpayer transferred its lucrative package insurance business to an unrelated insurer, which then reinsured it with the taxpayer's affiliate in Bermuda. The net result was to shift the profits of the business (which were very high since UPS almost never loses packages) from the US to Bermuda. The Court of Appeals accepted the taxpayer's argument that since the underlying business was profitable this satisfied the objective prong, without regard to whether the transfer was motivated by anything other than tax considerations. But UPS is distinguishable because of the intervening unrelated insurer and because there was nothing left in the US, whereas in the Caterpillar restructuring CSARL remained heavily involved in the US and in fact the Caterpillar and CSARL parts businesses were completely intermingled after the transaction.

In addition, it is far from clear that UPS remains good law. There have been many economic substance cases since then which took a broader view of the doctrine, and in particular the recent STARS cases indicate that you cannot imbue a tax driven transaction with economic substance by using profitable investments as part of it because the key question is whether these profits would have been earned without the transaction, which is clearly true in Caterpillar's case. ${ }^{27}$

\footnotetext{
${ }^{24}$ CSARL 2009 report to audit team (January, 2010); CSARL chronology (2010).

${ }_{25}^{25}$ Steines report, 5.

${ }^{26}$ United Parcel Service of America Inc. v. Commissioner, 87 AFTR2d Par. 2001-1051 (11th Cir. 2001).

27 Salem Financial Inc. v. United States, No. 1:10-cv-00192 (United States Court of Federal Claims, SEPTEMBER 20, 2013); Bank of New York Mellon Corp. et al. v. Commissioner, 140 T.C. No. 2 (FEBRUARY 11, 2013).
} 
Thus, in my opinion the IRS would have had a good case to challenge Caterpillar's original restructuring on economic substance grounds. However, the IRS did not do so, and the relevant tax years are now closed and protected from further audit. Thus, Caterpillar succeeded in its tax strategy. But should it have engaged in it to begin with? To answer this question we need to address the knotty problem of corporate taxation and CSR.

\section{Taxation and Corporate Social Responsibility}

Should corporations pay tax?

The usual understanding of this question relates to the debate on whether there should be a corporate tax. Many observers have recently criticized the corporate tax, and some have defended it, but that is not the focus of this article. ${ }^{28}$ Instead, I will assume that the state wants to tax corporations, for whatever reason (a safe assumption, at least in the short to medium run). Given this assumption, I will address whether corporations should cooperate and pay the corporate tax, or should it engage in "strategic" tax behavior designed to minimize or eliminate its corporate tax burden?

The answer to this question is related to the voluminous debate around corporate social responsibility (CSR). ${ }^{29}$ From the perspective of the corporation, if engaging in

\footnotetext{
${ }^{28}$ For my view on this debate, as well as a review of the extensive literature, see Reuven S. Avi-Yonah, Corporations, Society and the State: A Defense of the Corporate Tax, 90 Va. L. Rev. 1193 (2004).

${ }^{29}$ For a review of this debate see Reuven S. Avi-Yonah, The Cyclical Transformations of the Corporate Form: A Historical Perspective on Corporate Social Responsibility, 30 Del. J. Corp. L. 767 (2005) and for previous literature see, e.g., Michael C. Jensen, Value Maximization, Stakeholder Theory, and the Corporate Objective Function, 12 Bus. Ethics Q. 235 (2002); see also Michael C. Jensen and William Meckling, The Theory of the Firm: Managerial Behavior, Agency Costs, and Ownership Structure, 3 J. Fin. Econ. 305 (1976). For different perspectives on CSR in general see also Michael J. Philips, Reappraising the Real Entity Theory of the Corporation, 21 Fla. St. U. L. Rev. 1061 (1994); C.A. Harwell Wells, The Cycles of Corporate Social Responsibility: An Historical Retrospective for the Twenty-first Century, 51 Kansas L. Rev. 77 (2002); William Allen, Our Schizophrenic Conception of the Business Corporation, 14
} 
CSR is a legitimate corporate function, then corporations can also be expected to pay taxes to bolster society as part of their assumption of CSR. If, on the other hand, CSR is illegitimate, there is a question whether corporations should try to minimize their tax payments as part of avoiding CSR and maximizing the profits of their shareholders.

The answer to the question of whether corporations should try to minimize their tax payments by any means that the law may permit thus depends on our view of CSR. That view, in turn, depends on our view of the corporation. Historically, three views of the corporation have emerged and rotated in cyclical fashion. ${ }^{30}$ The first is the view that the corporation is primarily a creature of the state (the "artificial entity" view). The second is that the corporation is an entity separate from both the state and from its shareholders (the "real entity" view). The third is that the corporation is merely an aggregate of its individual members or shareholders (the "aggregate" or "nexus of contracts" view). ${ }^{31}$

Cardozo L. Rev. 261 (1992); Cynthia A. Williams, Corporate Social Responsibility in an Era of Economic Globalization, 35 UC Davis L. Rev. 705 (2002); Ronald Chen and Jon Hanson, The Illusion of Law: The Legitimating Schemas of Modern Policy and Corporate Law, 103 Mich. L. Rev. 1 (2004)..

${ }^{30}$ See Avi-Yonah, Cyclical Transformations, supra.

- ${ }^{31}$ See Avi-Yonah, Cyclical Transformations, supra, and the literature cited therein. There has also been considerable philosophical debate on the corporation as a moral person. See, e.g., Christian List \& Philip Pettit, Group Agency: The Possibility, Design, and Status of Corporate Agents (2011); Michael Bratman, Faces of Intention (1999); Margaret Gilbert, Joint Commitment: How We Make the Social World (2014); Peter French, The Corporation as a Moral Person, 16 AM. PHIL. Q. 207 (1979). 
Each of these three views has different implications for the issue of tax and CSR.

Under the artificial entity view, the corporation owes its existence to the state and is granted certain privileges in order to be able to fulfill functions that the state would like to achieve. Thus, engaging in some forms of CSR is part of the corporation's mission, and paying corporate tax is one way of fulfilling the corporation's CSR obligations.

Under the real entity view, the corporation is similar to an individual citizen in its rights and obligations. Just like an individual citizen does not have a legal requirement to aid her follow citizens but is praised if she does so, so the corporation may not be required to engage in CSR, but corporate management should be encouraged if they do so. As for taxes, just like an individual citizen, a corporation is legally required to pay taxes, and is expected not to engage in over-aggressive tax planning to minimize its tax obligations.

The most interesting debate is under the aggregate or "nexus of contracts" view of the corporation, which is the dominant view among contemporary corporate scholars. ${ }^{32}$

\footnotetext{
${ }^{32}$ See, e.g., Kenneth J. Arrow, Social Responsibility and Economic Efficiency, 21 Pub. Policy 303, 303-07 (1973); Friedrich A. Hayek, The Corporation in a Democratic Society, in Whose Interest Ought It and Will It Be Run, in Management and Corporations (Melvin Anshen \& George L. Bach, eds., 1960), at 99; Friedman, supra. The classic case affirming this "shareholder primacy" doctrine is Dodge v. Ford Motor Co., 204 Mich. 459, 170 N.W. 688 (1919), at 507. See also the classic debate between Berle and Dodd (Adolph A. Berle, Corporate Powers as Powers in Trust, 44 Harv. L. Rev. 1049 (1931); Merrick Dodd, For Whom Are Corporate Managers Trustees, 45 Harv. Law Rev. 1145 (1932); Berle, For Whom Are Corporate Managers Trustees: A Note, 45 Harv. Law Rev. 1365 (1932).) The shareholder primacy doctrine has become a mainstay of modern corporate law. See, e.g. Henry Hansmann \& Reinier Kraakman, The End of History for Corporate Law, 89 Geo. L.J. 439, 441, 449-451 (2001) (shareholder primacy likely to dominate future development of corporate law); Frank H. Easterbrook and Daniel R. Fischel, the Economic Structure of Corporate Law 12 (1991) (stating that shareholders, as residual claimants, have implicitly contracted for promise that firm will maximize profits in long run); Henry G. Manne \& Henry C. Wallich, The Modern Corporation and Social Responsibility (1972) (noting that social responsibility of corporations is shareholder wealth maximizing); Bernard Black and Reinier Kraakman, A Self-Enforcing Model of Corporate Law, 109 Harv. L. Rev. 1911 (1996) (arguing that principal goal of corporate law is to maximize shareholder wealth);see also Michael Bradley, Cindy A. Schipani, Anant K. Sundaram and James P. Walsh, The Purposes and
} 
Under this view CSR is an illegitimate attempt by managers to tax shareholders without their consent, and leads to managers being unaccountable to the shareholders that elected them. If so, management can be argued also to have a responsibility to maximize shareholder profits by minimizing corporate taxes as much as possible.

This article will argue that this view, when taken to extremes, is misguided. If corporations are not permitted to engage in CSR, then all social responsibility functions devolve on the state. Both taxing and spending become, to use Milton Friedman's language, purely governmental functions. But if corporate managers are required to minimize tax payments as much as possible, that could mean that the state is left without adequate resources to fulfill its governmental function. Thus, the aggregate view of the corporation, taken to its logical extreme, is self-defeating,

Accountability of the Corporation in Contemporary Society: Corporate Governance at a Crossroads, 62 Law \& Contemp. Probs. 9 (1999); Roberta Romano, The Political Economy of Takeover Statutes, 73 Va. L. Rev. 111, 113 (1987) (asserting that core goal of corporate law is to maximize equity share prices); ); Daniel J.H. Greenwood, Fictional Shareholders: For Whom Are Corporate Managers Trustees, Revisited, 69 S. Cal. L. Rev. 1021, 1023 (1996) ("[A]ll but the communitarians agree that virtually the sole task of corporate law is to ensure that managers act as agents for the shareholder owners."); cf. John C. Coffee, Jr., Unstable Coalitions: Corporate Governance As a Multi-Player Game, 78 Geo. L.J. 1495 (1990) (discussing role of stakeholders in firm); Lucian Bebchuk and Jesse Fried, Pay Without Performance (2004) (discussing need to align managerial incentives with shareholder interests). For arguments on the other side see Cynthia A. Williams, Corporate Social Responsibility in an Era of Economic Globalization, supra (it is debatable whether Hansmann and Kraakman's statement about shareholders' control of the corporation is accurate in the United States. In fact, one of the striking features of American corporate law is how little real control shareholders have, given that they are the "owners" of the corporation); Margaret M. Blair \& Lynn A. Stout, A Team Production Theory of Corporate Law, 85 Va. L. Rev. 247, 310 (1999) (where shareholders are widely dispersed, shareholders' voting rights are practically meaningless, given collective action problems, shareholders' rational apathy, and the power top managers exercise in nominating the candidates for the board and in otherwise shaping the voting agenda); Lawrence E. Mitchell, A Theoretical and Practical Framework for Enforcing Corporate Constituency Statutes, 70 Tex. L. Rev. 579, 630-43 (1992) (arguing that courts should modify corporate law to grant stakeholders standing to sue directors when the former are harmed by corporate action); Marleen A. O'Connor, The Human Capital Era: Reconceptualizing Corporate Law to Facilitate Labor-Management Cooperation, 78 Cornell L. Rev. 899, 936-65 (1993) (arguing that corporate law should be changed to encourage employee representation on the board and standing to sue); David Millon, Theories of the Corporation, 1990 Duke L.J. 201, 261-62 (praising case law that reaffirms directors' discretion to consider nonshareholder interests). See generally Progressive Corporate Law (Lawrence E. Mitchell ed., 1995) (surveying recent nontraditional approaches to corporate legal scholarship); Developments in the Law - Corporations and Society, Harvard Law Review, (2004), $2176-2177$. 
because it could mean that neither corporations nor the government can fulfill their responsibilities to society. That is not an acceptable outcome.

The following discussion is divided into three parts. Part III of the article briefly summarizes the development of the three views of the corporation. Part IV applies these three views to the question whether corporations should seek to minimize their corporate tax. Part V concludes by applying these answers to the case study introduced above.

\section{The Three Views of the Corporation: A Historical Perspective ${ }^{33}$}

Historically, the corporation evolved from its origins in Roman law in a series of four major transformations. First, the concept of the corporation as a separate legal person from its owners or members had to be developed, and this development was only completed with the work of the civil law Commentators in the fourteenth century. By the end of the Middle Ages, the membership corporation, i.e., a corporation with several members who chose others to succeed them, had legal personality (the capacity to own property, sue and be sued, and even bear criminal responsibility) and unlimited life, was well established in both civil and common law jurisdictions. The next important step was the shift from non-profit membership corporations to forprofit business corporations, which took place in England and the U.S. in the end of the eighteenth and beginning of the nineteenth century. The third transformation was the shift from closely-held corporations to corporations whose shares are widely held

\footnotetext{
${ }^{33}$ This part is based on Avi-Yonah, Cyclical Transformation, supra.
} 
and publicly traded, and with it the rise of limited liability and freedom to incorporate, which took place by the end of the nineteenth century and the beginning of the twentieth. Finally, the last major transformation was from corporations doing business in one country to multinational enterprises whose operations span the globe, which began after World War II and is still going on today.

Each of these four transformations (as well as a smaller, more temporary one which occurred in the U.S. in the 1980s with the advent of hostile takeovers) was accompanied by changes in the legal conception of the corporation. What is remarkable, however, is that throughout all these changes spanning two millennia, the same three theories of the corporation can be discerned. Those theories are the aggregate theory, which views the corporation as an aggregate of its members or shareholders; the artificial entity theory, which views the corporation as a creature of the state; and the real entity theory, which views the corporation as neither the sum of its owners nor an extension of the state, but as a separate entity controlled by its managers. $^{34}$

Each of these theories has different implications for the legitimacy of CSR, as indicated in the following table:

\footnotetext{
${ }^{34}$ These three theories are the standard ones in the literature. See, e.g., Millon, supra. For a full exposition of these developments see Avi-Yonah, Cyclical Transformations, supra.
} 
Table 1: Theories of the Corporation and CSR

$\begin{array}{lccc}\begin{array}{l}\text { Theory } \\ \text { Type of CSR }\end{array} & \text { Aggregate } & \text { Real } & \\ \begin{array}{l}\text { For long-run benefit } \\ \text { of shareholders }\end{array} & \text { Yes } & \text { Yes } & \text { Yes } \\ \begin{array}{l}\text { Not for shareholders, } \\ \begin{array}{l}\text { Corporation responsible } \\ \text { Not for shareholders, }\end{array}\end{array} & \text { No } & \text { Yes } & \text { Yes } \\ \begin{array}{l}\text { Corporation not responsible } \\ \text { No }\end{array} & \text { No } & \text { Yes }\end{array}$

The first type of CSR involves activities that can clearly and demonstrably benefit shareholders in the long run. For example, actions that prevent environmental disasters or comply with legal and ethical rules can have a significant positive effect in preventing disastrous corporate calamities, even if they cost money in the short run. Thus, even proponents of the aggregate theory, the currently dominant theory of the corporation in academic circles, would support this type of CSR.

The second type of CSR involves activities that are designed to mitigate social harms the corporation was responsible for, even when there is no direct legal responsibility, and when no benefit to the shareholders can be shown. Under the aggregate theory, such activities should not be permitted because they do not benefit shareholders. But under the artificial entity theory, since it emphasizes the benefits of corporate existence derived from the state, an implicit contract can be inferred that the 
corporation will help the state in mitigating harms that it causes even in the absence of legal responsibility. Otherwise, the state will have to bear this burden imposed by the corporation it created.

Finally, the third type of CSR involves activities like AIDS prevention, for which the corporation is not responsible and which in most cases do not benefit its shareholders, even in the long run. This type of CSR would not be permitted under the aggregate or artificial entity theories. But under the real entity theory, since the corporation is regarded as a person just like individuals, it is permitted to act philanthropically just like individuals are, and should in fact be praised to the extent it does so. ${ }^{35}$ Thus, under the real theory, even CSR activities that have nothing to do with benefiting shareholders or with direct corporate responsibility are permitted.

The aggregate or nexus of contracts theory has been dominant in US academic circles in recent years, but less so elsewhere. To understand why, a comparative perspective is needed. Political economists distinguish among three types of advanced capitalist societies. Under the "varieties of capitalism" framework, economies can be differentiated by their comparative institutional advantages. In general, economies can be characterized as either liberal (market economies, such as the US and the UK), corporatist (organized market economies that rely on tightly integrated private and networked associations to resolve significant dilemmas of economic integration, such

\footnotetext{
${ }^{35}$ JB White, From Expectation to Experience: Essays on Law \& Legal Education (1999).
} 
as Germany and Japan), or statist (depending on hierarchical solutions in resolving coordination problems, such as France). ${ }^{36}$

The varieties of capitalism framework suggest that firms in each of the three models of economic governance will distinguish themselves in different fields. In liberal market economies, the advantages of a flexible regulatory structure benefits industries targeting low costs and those operating in sectors characterized by radical innovation (e.g., software, bio technology). In corporatist economies, high levels of business coordination benefit sectors that rely on long-term contracts, and firms specialize in high quality, scale intensive and specialized supplier industries (autos, machine tools, chemicals). Statist economies favor large scale-intensive industries that have long time horizons or require major capital investment (autos, transport). ${ }^{37}$

There is an obvious correlation between the three varieties of capitalism described by political economists and the three historical theories of the firm outlined above. The liberal model of the UK and the US, with its emphasis on arm's length relationships and public trading, best first the aggregate theory of the firm. The statist, hierarchical model of France, with its emphasis on the relationship between the firm and the state, best fits the artificial entity model. And the German and Japanese style corporatist model best fits the real entity theory.

\footnotetext{
${ }^{36}$ Peter A. Hall and David Soskice (eds.), Varieties of Capitalism: The Institutional Foundations of Comparative Advantage (2001).

${ }^{37}$ Orfeo Fioretos, Varieties of Capitalism, Institutional Change, and Multilateralism in Post-War Europe (2004), 11-12.
} 
This relationship can also explain why in Europe CSR is much less controversial than in the US. Practically every EU government (including even the UK) has programs designed to foster CSR. ${ }^{38}$ These kind of programs are hard to imagine in the US context given the widespread hostility to CSR.

Fundamentally, therefore, the debate around CSR is linked to another wide-spread debate in corporate law: Whether corporate law is destined to "converge" on the US model of publicly traded corporations with dispersed share ownership, or whether other models (such as the German and Japanese models) are viable. The aggregate, nexus of contracts theory is closely linked to the US corporate governance model, while other models are much more open to CSR. Recent literature has given rise to doubts about the convergence hypothesis, but this debate will no doubt continue. ${ }^{39}$

As I have shown elsewhere, however, even in the US context the aggregate theory has not always been dominant. ${ }^{40}$ In fact, throughout most of the history described above, the real entity theory was the dominant one, and it can be argued that in practice most corporations are still operating on the basis of the real theory, not the aggregate one. Thus, CSR, which as we have seen is most easy to justify in all its forms on the basis of the real theory of the corporation, is likely to remain practiced for the future. The debate on CSR should therefore in my opinion shift from whether CSR is acceptable

\footnotetext{
${ }^{38}$ European Commission, Corporate Social Responsibility: National Public Policy in the European Union (2004).

${ }^{39}$ Mark J. Roe, A Political Theory of American Corporate Finance, 91 Colum. L. Rev. 10 (1991); Lucian A. Bebchuk and Mark J. Roe, A Theory of Path Dependence in Corporate Ownership and Governance, 52 Stan. L. Rev. 127 (1999); Mark D. West, The Puzzling Divergence of Corporate Law: Evidence and Explanations from Japan and the United States, 150 U. Pa. L. Rev. 527 (2001).

${ }^{40}$ Avi-Yonah, Cyclical Transformations, supra.
} 
to how to make it more accountable and effective in obtaining social goals- but that is an issue for another day. ${ }^{41}$

\section{Implications of the Three Views for CSR and the Corporate Tax}

What are the implications of the three views of the corporation summarized above for the question with which we began, i.e., whether corporations should pay the corporate tax (assuming that a corporate tax is imposed)?

This is not just a theoretical question, because in fact corporations have significant leeway about whether they should pay the tax imposed on them. In the US, revenues from the corporate income tax amounted to about a quarter of all federal tax revenues in 1965; today the tax accounts for less than $10 \%$ of revenues and that number is declining. ${ }^{42}$ A major reason in recent years for this decline is the growth of a corporate tax shelter industry, in which some of America's best minds scour the Code for ways to reduce corporate tax liabilities by various transactions and then sell these transactions for high fees to corporate clients. ${ }^{43}$ Estimates of the revenue loss vary, but there is a consensus that it is significant.

\footnotetext{
${ }^{41}$ See James P. Walsh and Reuven S. Avi-Yonah, The Unfettered Corporation: Corporate Social Responsibility and the Coming Crisis of Corporate Control, forthcoming.

${ }^{42}$ Corporate tax rates were higher before 1986, but the base was narrower, so that the 1986 tax reform act (which reduced the rate from $46 \%$ to the current $35 \%$ ) actually raised taxes on corporations. However, the effective tax rates today are close to what they were before 1986. See Yin.

${ }^{43}$ See, e.g., Joseph Bankman, The New Market in Corporate Tax Shelters, 83 Tax Notes 1775 (1999); David A. Weisbach, The Failure of Disclosure as an Approach to Shelters, 54 SMU L. Rev. 73 (2001); George K. Yin, Getting Serious about Corporate Tax Shelters, 54 SMU L. Rev. 209 (2001).
} 
The decline in corporate tax revenues is even more pronounced on a world-wide basis, and especially among developing countries that have traditionally relied on the corporate tax for a much higher percentage of total revenues than OECD member countries. ${ }^{44}$ There are two likely reasons for this overall decline. The first is an increase in aggressive tax behavior among corporations, especially in the case of developing countries that lack the resources to effectively counter such strategic tax planning behavior, such as abusive transfer pricing. The second is tax competition among countries to attract corporate investments, which has grown significantly in the last two decades. ${ }^{45}$ This competition enables companies like Intel to pay no tax at all on its non-US income. The most recent manifestation of this trend has been inversion transactions, in which US-based corporations nominally move their headquarters to a tax haven like Bermuda. This type of transaction can result in a dramatic decrease in worldwide effective tax rates for the inverting corporation. ${ }^{46}$

In what follows, I will discuss the implications of each of the three views of the corporation for the attitude that the corporation should take to paying the corporate tax.

\footnotetext{
${ }^{44}$ In developing countries the corporate tax can amount to as much as $25 \%$ of total tax revenues, see World Bank, Tax Policy Handbook 165 (Parthasarathi Shome ed., 1995). The average from 1990 to 2001 was $17 \%$, as opposed to $7 \%$ in developed countries: Michael Keen and Alejandro Simone, Is Tax Competition Harming Developing Countries More Than Developed? 34 Tax Notes Int'l 1317 (2004). Keen and Simone show that from 1990 to 2001 corporate tax rates have declined in both developed and developing countries. However, while in developed countries this decline in the rates was matched by a broadening of the tax base, so that no decline in revenues can be observed, in developing countries the same period witnessed a decline of corporate tax revenues by about 20 percent on average.

${ }^{45}$ Reuven S. Avi-Yonah, Globalization, Tax Competition, and the Fiscal Crisis of the Welfare State, 113 Harv. L. Rev. 1573 (2000); Julie Roin, Competition and Evasion: Another Perspective on International Tax Competition, 89 Geo. L.J. 543 (2001).

${ }^{46}$ Reuven S. Avi-Yonah, For Haven's Sake: Reflections on Inversion Transactions, 95 Tax Notes 1793 (June 17, 2002)
} 


\section{a. The Artificial Entity View.}

From the artificial entity view the corporation is a creature of the state. The state creates it and bestows various legal advantages on it, such as legal personality and limited liability. The state also creates the conditions for the corporation to operate in the market by providing defense and a property rights regime, as well as building infrastructure and educating workers.

The implication of this view for CSR, as noted above, is that the corporation is obligated not to impose additional burdens on the state that created it. Thus, to the extent the corporation's own activities result in additional burdens (e.g., by creating pollution), the corporation is obligated to remedy that situation.

It is less clear that the artificial entity view requires or permits corporations to engage in CSR that is unrelated to their activities. While historically the state created corporations "imbued with a public purpose", developments since the mid-19 $9^{\text {th }}$ century (such as general incorporation and the decline of ultra vires) have led to the view that the corporation fulfills its purpose sufficiently in engaging in its normal for profit activities, and should not be required to do more.

However, precisely that limitation also has implications for the corporate tax. To the extent the corporation is free to pursue purely for profit activities, as long as those do 
not impose a burden on the state, the state is left with the obligation to carry to weight of social responsibility on its own. For example, if there is a health crisis that the corporation did not contribute to creating, such as AIDS, the state and not the corporation has the obligation to address it. But this means that the state needs resources, and a major way of obtaining these resources is to impose taxes, including the corporate tax.

I would therefore argue that under the artificial entity view corporations have an affirmative obligation not to engage in aggressive tax planning designed to reduce their tax burden. The state created the corporation and the conditions for its operation in the market. In return, the state may legitimately expect corporations not to impose additional burdens on it. But since the state and not the corporation bears the burden of most social obligations under this model, the state can also expect the corporation to contribute its fair share to the ability of the state to fulfill its obligations to its citizens. This means that when the corporation engages in aggressive tax planning such as corporate tax shelters or abusive transfer pricing, it is breaching an implicit bargain with the state that created it, gave it legal rights, and created the conditions for it to make those same profits it is attempting to shield from tax.

Of course, this begs the question of how to distinguish abusive tax evasion from legitimate tax avoidance. But while this is a hard question to answer from the government's perspective, or in a court of law, it is less unclear from the corporation's perspective. Most corporate tax managers know very well when a 
transaction is tax motivated as opposed to having a non-tax business reason. Thus, a corporation can be legitimately expected to police its own behavior in this regard, without worrying too much about where the line should be drawn. ${ }^{47}$

\section{b. The Real Entity View.}

Under the real entity view, the corporation is similar to an individual. It is an entity made up of people (corporate managers and employees) that is separate from both the state and from its shareholders. ${ }^{48}$ The implication for CSR is that our view of CSR activities that are unrelated to the corporation, but are beneficial to society at large, should be the same as our view of such behavior by individuals: It should not be legally required, but is praiseworthy and should be encouraged when it happens. This is the view most management takes of CSR, and judging by their advertising, the view of the general public as well.

What are the implications of the real view for corporate strategic tax behavior? Judge Learned Hand famously stated in 1935 that there is "not even a patriotic duty" for

\footnotetext{
${ }^{47}$ The exception would be tax competition, which can be argued represents legitimate business planning from the corporation's perspective.

${ }^{48}$ As one sociologist has stated, "[t]he recurrent problem in sociology is to conceive of corporate organization, and to study it, in ways that do not anthropomorphize it and do not reduce it to the behavior of individuals or of human aggregates." Guy E. Swanson, The Tasks of Sociology, 192 Science 665 (1976). A whole branch of economic sociology centers on the study of organizations, and there are numerous books devoted to the topic. See, e.g., James D. Thompson, Organizations in Action: Social Science Bases of Administrative Theory (1967, reissued 2003); W. Richard Scott, Organizations: Rational, Natural, and Open Systems (5 ${ }^{\text {th }}$ ed. 2003); Jeffrey Pfeffer and Gerald R. Salancik, The External Control of Organizations: A Resource Dependence Perspective (1978, reissued 2003); Walter W. Powell and Paul j. DiMaggio (eds.), The New Institutionalism in Organizational Analysis (1991); Neil J. Smelser and Richard Swedberg (eds.), The Handbook of Economic Sociology (1994), especially Part II, Section C, The Sociology of Firms, Organizations, and Industry. Most of these books revolve around the study of large corporations, since these are the dominant forms of organization in this society.
} 
citizens to pay their taxes; instead, it is the state's obligation to force them to do so. But even if that statement could be taken literally in 1935 (and there are grounds to doubt that Hand meant it seriously), it certainly cannot be applied in the post-World War II environment, in which the obligation to pay the income tax was shifted from the rich to the middle class. ${ }^{49}$ While much of the success of the US in collecting the income tax stems from its sophisticated use of withholding and information reporting, it is by no means true that nobody pays taxes voluntarily. If that were the case, the estimates for compliance in the absence of withholding or information reporting would be far below $70 \%$. The US tax system could not work unless the majority of its citizens were trying to abide by the law, not evade it.

The importance of voluntary compliance can also be demonstrated by the contrast between the US and countries in which there is no tax-paying "culture". The US is far more successful in collecting the taxes due than countries like Italy or than most developing countries, where the citizens indeed follow Hand's dictum (or even regard it as their patriotic duty not to pay taxes). The reason for the US' relative success, even in an era of sharp cutbacks in IRS audit and enforcement activity, is that most US citizens do regard it as their duty to try to comply with the tax law. That is also the reason why the US can depend on most residents filing a tax return and selfassessing their tax liability every April 15, even though the refund they typically get

\footnotetext{
${ }^{49}$ Hand's statement was dicta in the context of the most famous case shutting down an avenue of tax avoidance, Gregory v. Helvering. As Assaf Likhovski has shown, this statement (and the whole opinion) should be understood against the background of the contemporary hearings into tax evasion by rich and famous Americans such as Andrew Mellon. It seems to me that if pressed even Hand would acknowledge that the tax system could not work if everybody tried as hard as Mellon did to avoid paying their taxes. Assaf Likhovski, The Story of Gregory: How Are Tax Avoidance Cases Decided, in Steven A. Bank and Kirk J. Stark (eds.), Business Tax Stories 89 (2005).
} 
is without interest and means that they have been giving the government an interestfree loan.

In general, the modern literature on tax enforcement assumes that there exists an "enforcement pyramid" ${ }^{50}$ At the bottom are the majority of citizens whose inclination is to try to comply with the tax law. As you go up the pyramid, the appetite for avoidance increases and the number of citizens decreases, and the type of enforcement changes from cooperation and the provision of information to increasingly harsher enforcement measures. Where the pyramid is reversed and most citizens do not cooperate, enforcement fails. In that way tax law is no different than other laws: A modern state cannot exist unless most citizens could be expected to comply with the law most of the time.

From that perspective, if the real view of the corporation is the correct one, the implication is that the corporation should behave like an ordinary citizen: It should try to comply with the tax law to the best of its ability. Thus, it is legitimate for corporations to try to minimize taxes paid on ordinary business transactions, but it is not legitimate to engage deliberately in strategic tax behavior designed solely to minimize its taxes. As stated above, while this line is difficult for the government or a court to draw from the outside, it is not so hard to discern from the perspective of the corporation.

\footnotetext{
${ }^{50}$ John Braithwaite, Restorative Justice and Responsive Regulation (2003).
} 
Strangely from today's perspective, this was in fact the attitude that most corporations took to tax compliance before the 1990s. The tax function was not viewed as a profit center, and while corporations tried to minimize tax costs, large publicly held corporations did not engage in tax shelters (and were in fact quite conservative in tax matters). It was part of the corporation's general responsibility to society to pay its taxes, just like it is part of an individual's responsibility, and under the real view CSR is generally legitimate even if there is no connection between the uses of the funds and the corporation's own activities.

This attitude changed by the mid 1990s, and today major corporations like General Electric or Coltec have lost important tax shelter cases. ${ }^{51}$ Presumably, this shift in attitude was accompanied by a shift in the corporation's view of itself, as the aggregate view came to dominate the discussion and shareholder profit maximization became the sole legitimate goal of corporate activity. To this view, which poses the hardest challenge to CSR, we can now turn.

\section{c. The Aggregate View.}

How does strategic tax behavior appear from the aggregate perspective on the corporation? From this point of view, the sole legitimate function of the corporation is shareholder profit maximization, and any CSR activity that is not related to long-term

${ }^{51}$ Coltec v. US, 454 F.3d 1340 (Fed. Cir. 2006); TIFD III-E Inc. v. United States, No. 10-70 (2nd Cir., Jan. 24, 2012). 
profit maximization is an illegitimate "tax" imposed by management on the shareholders, without the accompanying democratic accountability.

It is easy to see how this view can lead to strategic tax behavior. If tax is considered a cost like any other cost imposed on the corporation, it behooves the management to try to minimize this cost, or even turn it into a profit. Thus, the goal of shareholder profit maximization can naturally lead to corporations trying to minimize taxes and thus enhance earnings per share.

In the early 1990s, two factors led an increasing number of corporations to adopt this view. First, management compensation was linked to earnings per share via stock options, and although this led to abuses in some cases (even leading to corporations like Enron paying additional taxes on fictitious earnings), in most cases the mechanism worked properly, inducing management to focus exclusively on increasing earnings per share. Second, consolidation in the accounting field led the "Big Four" accounting firms to try to move beyond their traditional audit functions to devising tax strategies to be sold to individual corporate clients.

Increasing competition among corporations and increasing pressure on top management to deliver higher EPS explains the rest. Once some firms adopted aggressive tax strategies and saw their effective global tax rate plunge and their EPS increase, management in other firms came under pressure to deliver similar results. It became commonplace for the $\mathrm{CEO}$ and $\mathrm{CFO}$, who never bothered to look at a lowly 
cost center like taxes before, to summon the Tax Director and require an explanation why their global effective tax rate was several percentage points higher than the competition. The Tax Director, who was already under pressure from the accounting firms to try out novel tax strategies, usually succumbed. Thus a significant number of conservative firms came to adopt aggressive tax strategies. The rhetoric of shareholder profit maximization came to provide a convenient cover and rationalization for this activity.

A good example of the spread of this type of strategic tax behavior is the saga of inversion transactions. Before 1997, most corporate managers assumed that shareholders would not tolerate a publicly traded US corporation reincorporating in Bermuda, despite the fact that such transactions could significantly reduce the overall effective tax rate. However, after Tyco inverted in 1997 and its stock price went up, there was increased pressure on competitors, resulting in about 15 more inversions. This wave only stopped after September 11, 2001, when public outcry against "unpatriotic" corporations and ensuing changes to the tax law blocked the phenomenon, at least temporarily. The inversions were defended in the name of shareholder profit maximization, even though as Desai has shown they may also have made it easier to fudge corporate accounts and harm shareholders. ${ }^{52}$

What is wrong with reducing taxes as a way of maximizing shareholder returns? The basic problem is that under the aggregate view most CSR activities are illegitimate. This necessarily means that they devolve upon the state, which is supposed to use its

\footnotetext{
${ }^{52}$ Mihir Desai, Earnings Management and Corporate Tax Shelters (2006).
} 
legitimate taxing function (unlike the illegitimate tax imposed by management upon the shareholders if the corporation engages in CSR) to raise money to fulfill these obligations. ${ }^{53}$ But if all corporations engage in strategic tax behavior, the state may not be able to raise sufficient money to fulfill its exclusive social responsibility functions.

It will immediately be argued that this scenario is unrealistic: since in OECD member countries the corporate tax amounts to less than $10 \%$ of total tax revenue, the state can replace the lost revenue from corporate tax avoidance by raising other taxes. But even if one sets aside issues of distribution and fairness (lowering taxes on capital usually means higher taxes on labor), this answer is inadequate for three reasons. First, there may be political constraints to raising other taxes; especially in the US context it seems glib to say that politicians could respond to a decline in the corporate tax by raising individual tax rates. Second, individual tax rates may already be set so high that it becomes highly inefficient and potentially counter-productive to raise them further. If individual rates are set very high, there will be an impact on both the labor/leisure trade-off and on the willingness of individuals to pay taxes, on which the system depends. Finally, in many non-OECD countries, as well as in some OECD members like Japan, the corporate tax amounts to a far higher percentage of total revenues. It has been shown that tax competition, which is itself a form of strategic

\footnotetext{
${ }^{53}$ In developed countries, the state may delegate some of its social responsibility to the non-profit sector. But this is no solution, since under the aggregate view for-profit corporations are prohibited from donating funds to non-profits as well, unless it can be shown that such contributions enhance shareholder returns (which is doubtful). Moreover, the non-profit sector is weak or non-existent in developing countries, where the CSR issue is most acute.
} 
tax behavior, has resulted in significant declines in tax revenues in developing countries, which have not been offset by tax increases elsewhere. ${ }^{54}$

It can also be argued that strategic tax behavior by corporations is positive in situations where the government is ineffective or corrupt, and therefore the funds can be put to better use in the private sector. This is precisely the reason that under the real view CSR is acceptable, because in many situations corporations are better situated than the government to address social problems. But this argument cannot be made under the aggregate view, because under that view almost all CSR is illegitimate and solving social problems is the exclusive responsibility of the government.

Thus, it seems to me that there is an internal contradiction in Friedman's argument, which the corporate tax shelter wave of the 1990s has brought out. If the sole function of corporations is profit maximization, it seems to follow that corporations should maximize profits by minimizing their taxes. But if all corporations avoid paying taxes, the result can be inadequate revenue for the government to fulfill those obligations that under the aggregate view it bears the sole responsibility for. The result would be that neither corporations nor the government can address social problems, and I do not think even Friedman would regard that outcome as desirable.

I would thus argue that even under the extreme version of the aggregate view, corporations do have an affirmative obligation to pay their taxes, so as to enable the

\footnotetext{
${ }^{54}$ Keen and Simone, supra.
} 
state to carry out those functions that they are barred from pursuing since they are unrelated to the goal of shareholder profit maximization. This, in fact, can be seen as another justification of imposing tax on the corporation: Rather than bear any social responsibility, the corporation can by paying its taxes shift that responsibility to the state, where it belongs.

Thus, strategic tax behavior seems to be inconsistent with any view of the corporation. Under the artificial entity view, it undermines the constitutive relationship between the corporation and the state. Under the real view, it runs contrary to the normal obligation of citizens to comply with the law even in the absence of effective enforcement. And under the aggregate view, it is different from other forms of shareholder profit maximization in that it weakens the ability of the state to carry out those functions that the corporation is barred from pursuing. It would thus seem that whatever view management takes of its relationship to the shareholders, to society and to the state, it is never justified in pursuing tax strategies that have as their only goal minimizing the corporation's tax payments to the government.

\section{Conclusion: Just Say No}

From the corporation's perspective, it thus seems that whatever our view of the nature of the corporation, it should not be permitted to engage in strategic behavior that is designed solely to minimize its taxes. From an artificial entity perspective such 
behavior undermines the special bond between the state and the corporations it created. From the real entity perspective such behavior is as unacceptable as it would be if all individual citizens engaged in it. And from an aggregate perspective strategic tax behavior does not leave the state adequate revenues to fulfill the increased obligations imposed on it by forbidding corporations to engage in CSR.

What are the implications for a case like Caterpillar?

Most US corporations nowadays acknowledge that in addition to maximizing profits and value for their shareholders, they also have a responsibility to other stakeholders such as their employees and customers, as well as to US society. It is rare to find a US-based multinational that does not declare on its web site that it is committed to CSR, despite the critiques launched against CSR in academic circles.

Until the early 1990s, most large US corporations also did not engage in aggressive strategies designed to reduce their US tax obligations. In my experience as a tax lawyer in the late 1980s and early 1990s, corporations engaged tax counsel to advise them on the most tax efficient structure of a deal that was motivated by valid business purposes. Large corporations did not engage in tax shelters or other transactions motivated primarily by tax considerations.

This situation changed in the past 25 years. Starting in the late 1980s, accounting firms and other promoters started selling sophisticated tax shelters to large corporate clients. These shelters were not motivated by business considerations. They were 
driven by tax and dressed up to appear as a valid business deal. The first major litigated case involving such a shelter was ACM, which was a partnership between Merrill Lynch (the promoter), Colgate and a Dutch bank, designed to create and artificial capital loss. In the period between 1990 and 2004 such corporate tax shelters designed by outside promoters proliferated and were adopted by most large US corporations. Ultimately, it took hearings before the US Senate Permanent Subcommittee on Investigations in 2003 to expose the scope of the corporate tax shelter phenomenon. This in turn led to changes in the tax law (codification of the economic substance doctrine), to changes in the ways accountants and lawyers are regulated, to new disclosure rules, and to a series of IRS victories in court which seem to have eliminated corporate tax sheltering for the time being.

But the underlying problem persists: The prevailing attitude among large US corporations now seems to be that aggressive tax planning that is not motivated by business purposes is justified because of competitiveness considerations ("everyone does it, especially our foreign competitors") and because it enhances shareholder value. The argument seems to be that paying taxes is a cost that reduces corporate profits and this negatively impacts the value of the shares. Thus, some US corporations engaged in so-called inversion transactions in which they nominally became subsidiaries of a foreign parent (typically in Bermuda) with no substantive change in their business (the headquarters stayed in the US) because these transactions enabled them to strip profits out of the US and the reduction in the US effective tax rate translated into higher share values. 
There are several problems with this type of argument. First, US corporations somehow managed to do without such aggressive tax planning for many decades without impeding either their competitiveness or their market valuation. Second, there is no clear evidence that a reduction in the effective US tax rate translates into higher share values; stock market prices are influenced by many factors and there are plenty of publicly traded US corporations that derive most of their profits from the US, pay a high US effective tax rate, but nevertheless have high stock prices. Third, if US corporations do not pay their fair share of tax, someone else has to pay, and shifting the tax burden to others (including to your own shareholders who are also taxpayers) hardly seems like a good way of maintaining CSR. Good citizenship includes paying the "price of civilization", especially since the value of the shares also depends on public goods like education, infrastructure and defense that have to be paid for by tax revenues.

In the Caterpillar case, a legendary US corporation was induced by a major US accounting firm to shift its tax planning in a way that moves a significant part of its profits from the US to Switzerland, without changing the underlying business model. There are ways in which the IRS can combat this type of tax aggressiveness, but it failed to do so, perhaps because at the time it was confronted with a deluge of even more aggressive shelters, and it did not have access to all the information that became public at the 2014 Senate hearing. I suspect that there are other cases in which major corporations were able to engage in tax strategies that they knew lacked economic 
substance and were not adequately challenged by the IRS. The IRS cannot be expected to overcome a determined effort to reduce taxes by any means by most large public US corporations. Nor do I think the various post 2003 changes will prevent a new wave of corporate tax shelters in the future; inversion are already back despite the enactment of Code section 7874 in 2004.

Therefore, in the end, I believe that the only real solution is to change the attitude of major US multinationals back to where it was when the 1986 Tax Reform Act was enacted. Back then, a tax director of a major US multinational would typically see aggressive tax motivated transactions as inconsistent with CSR, and would simply reject them if brought to him. The proper response of a corporate tax director to a proposed transaction that he or she knows is not motivated by a valid business purpose (even if it can be dressed up like one and even if he or she thinks it might possibly prevail in litigation) is to just say no. 